\title{
PENGARUH MODEL PEMBELAJARAN KOOPERATIF TIPETHINK PAIR SHARE (TPS) TERHADAP KEMAMPUAN PEMAHAMAN KONSEP MATEMATIS SISWA KELAS X SMA NEGERI 3 BINJAI TAHUN PELAJARAN 2017/2018
}

\author{
Faqih Hakim Hasibuan \\ Universitas Muslim Nusantara Al-Washliyah Medan \\ Jalan Sisingamangaraja, No. 2, Harjosari III, \\ Medan Amplas, Medan Kota, Kota Medan, Sumatera \\ E-mail: faqihhakimhsb@yahoo.com
}

\begin{abstract}
Abstrak
Penelitian ini bertujuan untuk mengetahui pengaruh penggunaan model pembelajaran kooperatif tipe Think Pair Share (TPS) terhadap kemampuan pemahaman konsep matematis siswa. Penelitian ini, yang dilaksanakan di SMA Negeri 3 Binjai Tahun Pelajaran 2017/2018, merupakan penelitian eksperimen semu, dengan desain penelitian pretest and posttest control group design, Berdasarkan hasil penelitian, nilai rata-rata pretest kelas eksperimen 48,03 dan nilai rata-rata pretest kelas kontrol 46,33. Sedangkan nilai rata-rata post test kelas eksperimen 54,78 dan nilai rata-rata posttest kelas control 50,47. Terdapat pengaruh yang signifikan antara pembelajaran kooperatif tipe TPS terhadap kemampuan pemahaman konsep matematis siswa yang dapat dilihat dari hasil perhitungan uji regresi linier sederhana diperoleh $r_{\text {tabel }}=0,329$, sementara berdasarkan perhitungan yang telah dilakukan diperoleh $r_{\text {hitung }}=0,71$. Dari perhitungan terlihat bahwa $r_{\text {hitung }}>r_{\text {tabel }}(0,71>0,329)$. Dengan demikian hipotesis yang diajukkan diterima.
\end{abstract}

\section{Abstract}

This study aims to determine the effect of using the Cooperative Think Pair Share (TPS) type on the ability to understand students' mathematical concepts. This research, which was conducted in the 2017/2018 Academic Year 3 Binjai High School, was a quasi-experimental study, with the design of the pretest and posttest control group design. Based on the results of the study, the average value of the experimental class pretest was 48.03 and the average value of the control class pretest was 46.33 . While the average value of the experimental class post test is 54.78 and the average value of the control class posttest is 50.47 . There is a significant effect between TPS type cooperative learning on the ability to understand students' mathematical concepts which can be seen from the results of simple linear regression test calculations obtained rtable $=0.329$, while based on the calculations that have been done obtained $r$ count $=0.71$. From the calculation it can be seen that $r$ count $>r$ table $(0.71>0.329)$. Thus the proposed hypothesis is accepted.

Kata Kunci: Think Pair Share, Matematika, dan Pemahaman Konsep 


\section{Pendahuluan}

Pendidikan memegang peranan penting dalam mempersiapkan sumber daya manusia yang berkualitas. Dengan pendidikan, manusia juga dapat mengembangkan setiap potensi yang ada dalam dirinya untuk memiliki keterampilan yang diperlukan dalam bersaing di dunia kerja dan era globalisasi yang berkembang pesat. Perkembangan ilmu pendidikan dan teknologi menuntut perubahan pola pikir pendidik menjadi lebih modern. John Dewey menyatakan bahwa "Pendidikan merupakan proses pembentukan kemampuan dasar yang fundamental, baik menyangkut daya pikir atau daya intelektual, maupun daya emosional atau perasaan yang diarahkan kepada tabiat manusia dan kepada semuanya". ${ }^{1}$

Dalam pendidikan di sekolah, salah satu mata pelajaran yang wajib yaitu matematika. Menurut Alfrianto bahwa: "Matematika merupakan salah satu displin ilmu dalam dunia pendidikan yang memegang peranan penting dalam perkembangan sains dan teknologi. Matematika juga bermanfaat dalam pengembangan berbagai bidang keilmuan yang lain". ${ }^{2}$

Selain itu tujuan pembelajaran matematika adalah agar siswa memiliki kemampuan sebagai berikut: 1). Memahami konsep matematika, menjelaskan keterkaitan antar konsep dan mengaplikasikan konsep atau algoritma, secara luwes, akurat, efisien, dan tepat dalam pemecahan masalah. 2). Menggunakan penalaran pada pola dan sifat, melakukan manipulasi matematika dalam membuat generalisasi, menyusun bukti, atau menjelaskan gagasan dan pernyataan matematika. Berarti pemahaman konsep disini sangat diperlukan untuk mengetahui sejauh mana siswa menguasai materi yang diajarkan.

Pemahaman konsep tersebut perlu ditanamkan kepada peserta didik sejak dini yaitu sejak anak tersebut masih duduk dibangku sekolah dasar maupun bagi siswa sekolah lanjutan tingkat pertama dan tingkat atas. Di sana mereka dituntut mengerti tentang definisi, pengertian, cara pemahaman konsep maupun pengoperasian matematika secara benar,karena akan menjadi bekal dalam mempelajari matematika pada jenjang pendidikan yang lebih tinggi. Nasution menyatakan bahwa "Tanpa

\footnotetext{
${ }^{1}$ Syaiful Sagala, Konsep dan Makna Pembelajaran (Bandung: Alfebeta, 2009, hlm. 3.

${ }^{2}$ Relawati dan Nusrani, "Perbandingan Kemampuan Pemahaman Konsep Matematis Melalui Model Pembelajaran Core dan Pembelajaran Langsung pada Siswa SMP”, Jurnal Kajian Pendidikan dan Pengajaran, Volume 2, No. 2, Oktober 2016, hlm. 161.
} 
konsep, belajar akan sangat terhambat", ${ }^{3}$ Akan sangat sulit bagi siswa untuk menuju ke proses pembelajaran yang lebih tinggi jika ia belum memahami konsep sehingga menyebabkan nilai matematika siswa rendah. Hal ini sejalan dengan NCTM 2000 bahwa rendahnya nilai matematika siswa ditinjau dari lima aspek kemampuan matematis yaitu:1). Kemampuan pemecahan masalah matematis, 2). Kemampuan Komunikasi matematis, 3). Kemampuan Penalaran matematis , 4). Kemampuan Pemahaman Konsep matematis, 5). Kemampuan Koneksi matematis. Kemampuan pemahaman konsep matematis mampu membantu siswa senantiasa berpikir secara sistematis, menyelesaikan masalah matematika dalam kehidupan seharihari dan menerapkan matematika dalam berbagai bidang ilmu pengetahuan lain. Berdasarkan informasi dari guru matematika SMA Negeri 3 Binjai yaitu Hotmauli Sihaloho, S.Pd menyatakan bahwa sebagian siswa memiliki pemahaman konsep matematika yang rendah, hal itu terlihat bahwa banyak siswa yang belum mencapai Kriteria Ketuntasan Minimum (KKM) yaitu 80, dan sebagian besar materi yang telah diajarkan pada pertemuan sebelumnya.

Berdasarkan hasil observasi yang peneliti lakukan di SMA Negeri 3 Binjai khususnya kelas $X$, diketahui bahwa salah satu faktor yang menyebabkan hal ini adalah strategi pembelajaran yang kurang tepat yang menerapkan kurikulum 2013 dengan pendekatan saintifik. Langkah-langkah pembelajarannya adalah mengamati, menanya, mengeksplorasi, mengasosiasi dan mengomunikasikan. Hampir sebagian siswa mengalami kesulitan memahami konsep. Siswa yang memiliki kemampuan yang tinggi cenderung aktif dan menonjol dalam diskusi, sedangkan siswa yang memiliki kemampuan yang rendah cenderung pasif, hanya main-main dalam diskusi dan melihat temannya mengerjakan soal tanpa memahami pengerjaan soal.

Akibatnya, banyak siswa mengalami kesulitanmengerjakan soal bahkan jika soalnya berbeda. Proses ini menyebabkan keterlibatan siswa dalam proses pembelajaran kurang optimal dan siswa kurang mengembangkan ide-ide yang dimiliki sehingga kemampuan pemahaman konsep matematis siswa kurang optimal.

Dari hasil analisis tes pemahaman konsep yang diikuti 36 orang siswa diperoleh informasi bahwa terdapat 24 orang siswa memiliki tingkat pemahaman konsep pada kategori rendah, 7 orang siswa memiliki tingkat

${ }^{3}$ Relawati dan Nurasni, "Perbandingan Kemampuan ..., hlm. 162. 
pemahaman konsep pada kategori cukup, 5 orang siswa memiliki tingkat pemahaman konsep pada kategori baik. Dari hasil tersebut menunjukkan bahwa masih rendahnya kemampuan pemahaman konsep matematika siswa diSMA Negeri 3 Binjai. Ada banyak faktor yang mempengaruhi keberhasilan belajar yang ingin dicapai siswa, baik faktor internal siswa maupun eksternal seperti model pembelajaran yang digunakan, fasilitas, kemampuan guru dan lingkungan sosial. yang pertama kesiapan siswa dalam belajar bahkan siswa menganggap matematika itu bukan pelajaran yang menyenangkan, membosankan, dan tidak menarik.

Think Pair Share (TPS) merupakan "Strategi diskusi kooperatif yang memiliki prosedur secara eksplisit memberikan waktu untuk berpikir sehingga siswa dapat aktif mengekspresikan dirinya dalam pembelajaran di kelas dan memahami konsep".

Berdasarkan penjelasan diatas, maka peneliti tertarik untuk melakukan penelitian mengenai "Pengaruh Model Pembelajaran kooperatif tipe Think Pair Share (TPS)Terhadap Kemampuan Pemahaman Konsep Matematis Siswa Kelas X SMA Negeri 3 Binjai Tahun Pelajaran 2017/2018".

Berdasarkan uraian di atas, maka rumusan masalah dalam penelitian ini adalah: "Apakah terdapat pengaruh yang signifikanmodel pembelajaran kooperatif tipe Think Pair Share (TPS) terhadap kemampuan pemahaman konsep matematis siswa kelas X SMA Negeri 3 Binjai Tahun Pelajaran 2017/2018.

Cholis Sadijah mengatakan bahwa TPS merupakan salah satu model pembelajaran kooperatif yang memberi siswa waktu untuk berpikir dan merespon serta saling bantu satu sama lain. Sehingga model pembelajaran ini membantu siswa dalam memahami konsep. Think Pair Share (TPS) adalah suatu model pembelajaran kooperatif yang memberi sisa waktu untuk berpikir dan merespon serta saling bantu sama lain. Model ini memperkenalkan ide "waktu berpikir atau waktu tunggu" yang menjadi faktor kuat dalam meningkatkan kemampuan siswa dalam merespon pertanyaan. Pembelajaran kooperatif model Think Pair Share (TPS) ini relatif lebih sederhana karena tidak menyita waktu yang lama untuk mengatur tempat duduk ataupun mengelompokkan siswa. Pembelajaran ini melatih siswa untuk berani berpendapat dan menghargai pendapat teman. ${ }^{4}$

${ }^{4}$ Cholis Sadijah, Penerapan Pembelajaran Kooperatif Think Pair Share(TPS) (Malang: Lembaga Penelitian UM, 2006), hlm. 12. 
Menurut Ibrahim langkah-langkah pembelajaran kooperatif tipe TPSterdiri atas tiga komponen utama, yaitu Think (berpikir), Pair (berpasangan), dan Share (berbagi). ${ }^{5}$

\section{Tinjauan Pustaka}

1. Pembelajaran Matematika

Clements dan Battista mengemukakan bahwa "Pembelajaran hanya penyampaian fakta, konsep, prinsip, dan keterampilan kepada siswa". ${ }^{6}$ Dari makna ini terlihat bahwa pembelajaran merupakan interaksi dua arah dari seorang guru dan peserta didik, di mana antara keduanya terjadi komunikasi yang intens dan terarah menuju pada suatu target yang telah ditetapkan sebelumnya.Jadi, dapat disimpulkan bahwa pembelajaran matematika adalah rangkaian proses mempelajari matematika yang bertujuan untuk membantu pola pikir siswa agar dapat memahami konsep.

2. Pemahaman Konsep Matematis

Purwanto mengatakan bahwa"Pemahamanadalah tingkat kemampuan yang mengharapkan siswa mampu memahami arti atau konsep, situasi serta fakta yang diketahuinya". ${ }^{7}$ Menurut Gagne bahwa: "Konsep adalah suatu ide abstrak yang memungkinkan kita mengelompokkan objek ke dalam contoh dan non contoh". ${ }^{2}$

Siswa dapat dikatakan sudah memahami konsep matematis jika ia sudah dapat memahami suatu konsep matematika dengan berbagai permasalahan matematis, kemudian ia menghubungkan informasi yang sudah didapatkan sebelumnya dengan informasi yang baru, yang kemudian ia jadikan suatu pemahaman baru yang membantunya untuk menyelesaikan masalah matematis. Menurut Iskandar Zulkarnain dan Soraya Djamilah ada 7 indikator pemahaman konsep matematis yaitu : 1).Kemampuan menyatakan ulang konsep yang telah dipelajari, 2). Kemampuan klasifikasi objek-objek berdasarkan dipenuhi atau tidaknya persyaratan yang membentuk konsep

${ }^{5}$ Winda Verowita, "Pengaruh Penerapan Model Pembelajaran Kooperatif Tipe Think

Pair Share terhadap Pemahaman Konsep dalam Pembelajaran Matematika", Jurnal Pendidikan Matematika, Part 3 Volume 1, No. 1, 2012, hlm. 49.

${ }^{6}$ Trianto, Mendesain Model Pembelajaran Inovatif-Progresif, Jakarta: Kencana Prenada Media Group, 2011, hlm. 18.

${ }^{7}$ Ngalim Purwanto, Prinsip-Prinsip dan Teknik Evaluasi Pengajaran (Bandung: Remaja Rosdakarya, 2010), hlm. 44.

${ }^{8}$ Adesnayanti K. Duha, "Penerapan Model Think Pair Share terhadap Pemahaman Konsep Matematika", Jurnal Pendidikan Matematika, Volume 1, No. 1, 2012, hlm. 9. 
tersebut, 3). Kemampuan menerapkan konsep secara alogaritma, 4). Kemampuan memberikan contoh dan counter example dari konsep yang telah dipelajari, 5). Kemampuan menyajikan konsep dalam berbagai macam bentuk representasi matematika, 6). Kemampuan mengaitkan berbagai konsep (internal dan eksternal matematika), 7). Kemampuan mengembangkan syarat perlu dan atau syarat cukup suatu konsep. ${ }^{9}$

3. Pembelajaran Kooperatif Tipe Think Pair Share (TPS)

Aris Shoimin menyebutkan bahwa "Model pembelajaran kooperatif tipe Think Pair Share (TPS) merupakan strartegi diskusi kooperatif yang dikembangkan oleh Frank Lyman dan koleganya dari Universitas Maryland pada tahun 1981 ". ${ }^{10}$ Dalam TPS, para siswa berpasangan terdiri atas dua orang. Guru menyampaikan pelajaran, lalu siswa diberi LKS untuk dikerjakan masing-masing terlebih dahulu. Guru membimbing siswa yang kesulitan. Selanjutnyasiswa berpasangan untuk berdiskusi menentukan hasil jawaban yang dianggap benar, setelah itu barulah hasilnya dipresentasikan didepan kelas.

\section{Metodologi Penelitian}

Populasi dalam penelitian ini adalah seluruh siswa kelas X SMA Negeri 3 Binjai tahun pelajaran 2017/2018. Dalam penentuan pemilihan sampel ini, teknik sampling yang digunakan adalah Simple Random Sampling. Dikatakan Simple (sederhana) karena pengambilan anggota sampel dari populasi dilakukan secara acak tanpa memperhatikan strata yang ada dalam populasi itu.

Cara pengambilan sampel dalam penelitian sangatlah penting terlebih jika peneliti ingin hasil penelitiannya berlaku untuk seluruh populasi. Dari 8 kelas yang tersedia, sampel penelitian ini diambil sebanyak 2 kelas yaitu kelas $\mathrm{X}-\mathrm{MIA}^{3}$ dan kelas X-MIA ${ }^{4}$ SMA Negeri 3 Binjai, dimana kelas XMIA ${ }^{3}$ yang berjumlah 36 orang sebagai kelas Eksperimen dan kelas X-MIA ${ }^{4}$ yang berjumlah 36 orang sebagai kelas Kontrol. Dengan demikian sampel keseluruhan berjumlah 72 orang. Jenis penelitian ini adalah Quasi

9Iskandar Zulkarnain dan Soraya Djamilah, Penerapan Model Pembelajaran Think Pair Share Terhadap Kemampuan Pemahaman Matematis Siswa Sekolah Menengah Pertama, EDU-MAT Jurnal Pendidikan Matematika, Volume 3, Nomor 1, April 2015, hlm. 108-109.

${ }^{10}$ Aris Shoimin, Aris Shoimin, 68 Model Pembelajaran Inovatif dalam Kurikulum 2013, Yogyakarta: Ar-Ruzz Media, 2014, hlm. 209. 
eksperimen. Dalam penelitian ini, peneliti mengumpulkan data dengan memberikan perlakuan yang berbeda pada dua kelompok sampel penelitian.

Desain penelitian yang digunakan pada Quasi Eksperimen ini adalah Pretest-Posttesst control group design. Rancangan ini merupakan rancangan penelitian eksperimen yang dilakukan dengan pretest (tes awal) selanjutnya diberi perlakuan dan diakhiri dengan posttest. Data yang diperlukan dalam penelitian ini adalah kemampuan Pemahaman Konsep Matematika Siswa sebelum dan setelah diberi perlakuan. Instrumen yang digunakan untuk mengumpulkan data adalah tes, tes yang diberikan berupa tes uraian/essay sebanyak 5 soal.

\section{Hasil dan Pembahasan}

Penelitian menggunakan model pembelajaran kooperatif Tipe Think Pair Share (TPS)dikelas eksperimen dan model pembelajaran konvensional dengan model pembelajaran langsung dikelas kontrol. Sebelum dilakukan penelitian, kedua kelas tersebut diberi pretest, tujuannya untuk mengetahui kemampuan awal siswa sebelum diberi perlakuan pembelajaran.

\section{Data Nilai Pretest Kelas Eksperimen dan Kelas Kontrol}

Pretest adalah soal tes yang diberikan kepada siswa sebelum diberikan perlakuan pembelajaran. Berdasarkan data hasil pretest yang diberikan di kelas eksperimen dan di kelas kontrol pada lampiran 32, secara ringkas dirangkum pada tabel 4.1 berikut :

Tabel 4.1

Data Nilai Pretest Siswa Kelas Eksperimendan Kelas Kontrol

\begin{tabular}{|l|c|l|c|}
\hline \multicolumn{2}{|c|}{ Eksperimen } & \multicolumn{2}{c|}{ Kontrol } \\
\hline $\begin{array}{l}\text { Jumlah } \\
\text { Siswa }\end{array}$ & 36 & $\begin{array}{l}\text { Jumlah } \\
\text { Siswa }\end{array}$ & 36 \\
\hline Rata-rata & 48,03 & Rata-rata & 46,33 \\
\hline $\begin{array}{l}\text { Simpangan } \\
\text { Baku }\end{array}$ & 13,27 & $\begin{array}{l}\text { Simpangan } \\
\text { Baku }\end{array}$ & 12,95 \\
\hline Varians & 176,09 & Varians & 167,70 \\
\hline
\end{tabular}

Secara visual penyebaran data kemampuan pemahaman konsep matematika siswa kelas eksperimen dan kelas kontrol yang menggunakan model pembelajaran konvensional dapat dilihat dalam diagram batang perbedaan nilai rata-rata, simpangan baku, dan varians pretest kelas eksperimen dan kelas kontrol sebagai berikut : 


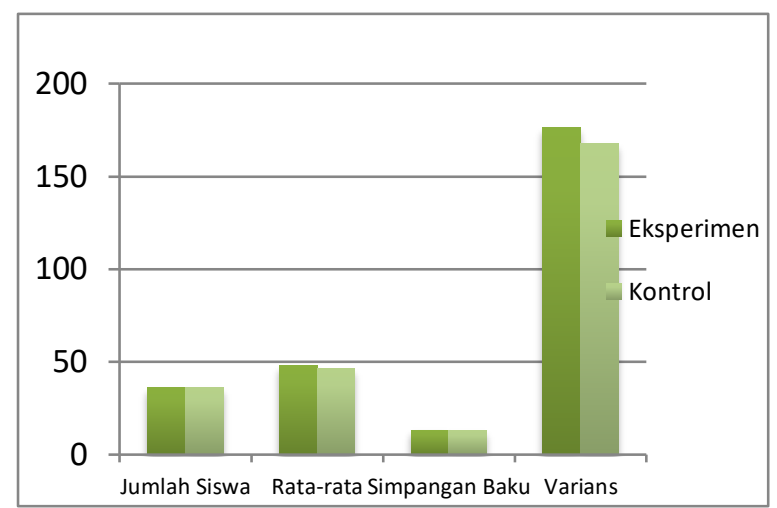

\section{Data Nilai Posttest Kelas Eksperimen dan Kelas Kontrol}

Posttest adalah soal tes yang diberikan kepada siswa setelah diberikan perlakuan pembelajaran. Berdasarkan data hasil posttest yang diberikan di kelas eksperimen dan di kelas kontrol pada lampiran 32, secara ringkas dirangkum pada tabel 4.2 berikut :

Tabel 4.2

Data Nilai Posttest Siswa Kelas Eksperimen dan Kelas Kontrol

\begin{tabular}{|l|c|l|c|}
\hline \multicolumn{2}{|c|}{ Eksperimen } & \multicolumn{2}{c|}{ Kontrol } \\
\hline $\begin{array}{l}\text { Jumlah } \\
\text { Siswa }\end{array}$ & 36 & $\begin{array}{l}\text { Jumlah } \\
\text { Siswa }\end{array}$ & 36 \\
\hline Rata-rata & 54,78 & Rata-rata & 50,47 \\
\hline Simpangan Baku & 14,67 & Simpangan Baku & 13,31 \\
\hline Varians & 215,21 & Varians & 177,15 \\
\hline
\end{tabular}

Secara visual penyebaran data kemampuan pemahaman konsep matematis siswa kelas eksperimen dan kelas kontrol yang menggunakan model pembelajaran konvensional dapat dilihat dalam diagram batang perbedaan nilai rata-rata, simpangan baku, dan varians posttest kelas eksperimen dan kelas kontrol sebagai berikut:

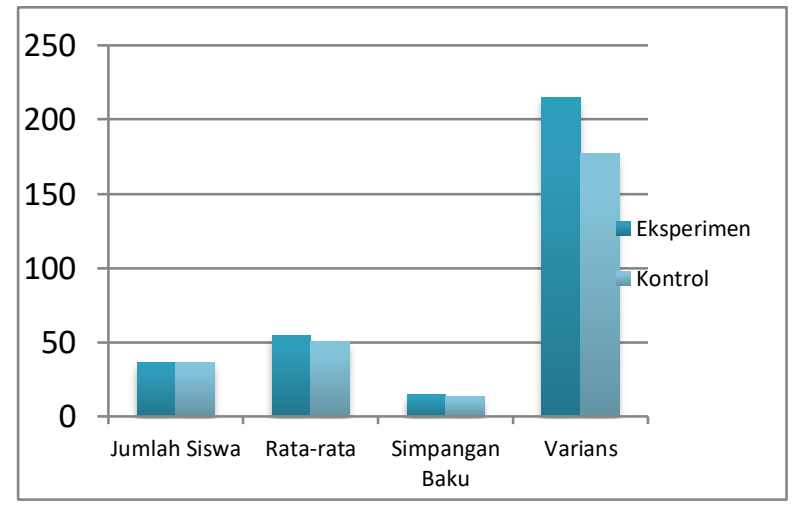


Analisis data hasil penelitian yang berupa tes kemampuan pemahaman konsep matematis siswa dilakukan untuk membuktikan hipotesis penelitian yang telah diajukan. Hasil uji prasyarat analisis hingga pengujian hipotesis akan dipaparkan sebagai berikut:

Uji normalitas yang digunakan adalah uji Liliefors. Uji Liliefors digunakan untuk mengetahui apakah data berasal dari populasi yang berdistribusi normal atau tidak, dengan ketentuan bahwa data berasal dari populasi yang berdistribusi normal jika memenuhi kriteria $L_{0}<L_{\text {tabel }}(0,1208<$ 0,1477 ) diukur pada taraf signifikansi dan tingkat kepercayaan tertentu.

Tabel 4.3

Rekapitulasi Hasil Perhitungan Uji Normalitas dengan Uji liliefors

\begin{tabular}{|c|c|c|c|c|c|}
\hline Data & Kelompok & $\mathbf{L}_{\mathbf{0}}$ & $\mathbf{L}_{\text {tabel }}$ & $\begin{array}{c}\text { Kesimpul } \\
\text { an }\end{array}$ & Ket \\
\hline \multirow{2}{*}{ Pretest } & Eksperimen & 0,1208 & 0,1477 & Terima $\mathrm{H}_{0}$ & Normal \\
\cline { 2 - 6 } & Kontrol & 0,1263 & 0,1477 & Terima $\mathrm{H}_{0}$ & Normal \\
\hline \multirow{2}{*}{ Posttest } & Eksperimen & 0,1216 & 0,1477 & Terima $\mathrm{H}_{0}$ & Normal \\
\cline { 2 - 6 } & Kontrol & 0,1463 & 0,1477 & Terima $\mathrm{H}_{0}$ & Normal \\
\hline
\end{tabular}

Uji homogenitas atau uji kesamaan dua varians populasi dilakukan dengan uji Fisher. Untuk kriteria pengujian data kedua sampel adalah homogen jika $F_{\text {hitung }}<F_{\text {tabel }}(1,05<1,76)$ pada taraf signifikan 5\%. Maka dinyatakan kedua kelas tersebut homogen.

Tabel 4.4

Rekapitulasi Hasil Perhitungan Uji Homogenitas dengan Uji Fisher
\begin{tabular}{|c|c|c|c|c|}
\hline Data & Kelompok & F $_{\text {hitung }}$ & F $_{\text {tabel }}$ & Kesimpulan \\
\hline \multirow{2}{*}{ Pretest } & Eksperimen & \multirow{2}{*}{1,05} & 1,76 & Homogen \\
\cline { 2 - 2 } & Kontrol & & & \\
\hline \multirow{2}{*}{ Posttest } & Eksperimen & \multirow{2}{*}{1,21} & 1,76 & Homogen \\
\cline { 2 - 3 } & Kontrol & & & \\
\hline
\end{tabular}

Pengujian Hipotesis, Setelah uji prasyarat, maka didapat bahwa kedua kelas berdistribusi normal dan homogen. Pengujian selanjutnya dilakukan dengan uji regresi linier sederhana.

\section{a. Analisis Regresi}

1. Regresi Pada Kelas Eksperimen

Model regresi linier antara variabel terikat $Y$ (Data posttest) dengan variabel bebas $X$ (Data Pretest) dinyatakan dalam $Y=a+b x$. 


$$
\mathrm{Y}=19,24+0,74 x
$$

2. Regresi Pada Kelas Kontrol

Model regresi linier antara variabel terikat $Y$ (Data posttest) dengan variabel bebas $\mathrm{X}$ (Data Pretest) dinyatakan dalam $\mathrm{Y}=\mathrm{a}+\mathrm{bx}$.

$$
\mathrm{Y}=18,80+0,68 x
$$

\section{Tabel 4.5}

Regresi Kelas Eksperimen dan Kelas Kontrol

\begin{tabular}{|c|c|}
\hline Kelas & Garis Regresi \\
\hline Eksperimen & $Y=19,24+$ \\
& $0,74 X$ \\
\hline \multirow{2}{*}{ Kontrol } & $Y=18,80+$ \\
& $0,68 X$ \\
\hline
\end{tabular}

\section{b. Uji Keberartian Koefisien}

1. Regresi pada Kelas Eksperimen dan Kelas Kontrol

Untuk menguji keberartian koefisien regresi dirumuskan hipotesis sebagai berikut:

\section{Tabel 4.6}

\section{Hasil Perhitungan Keberartian Koefisien Regresi Pada Kelas Eksperimen}

\begin{tabular}{||l|c|c|c|c||}
\hline $\begin{array}{c}\text { Sumber } \\
\text { Varians }\end{array}$ & DK & JK & RJK & F \\
\cline { 1 - 4 } $\operatorname{Reg}(\mathrm{a})$ & 1 & 108021,78 & - & \multirow{2}{*}{ F $_{\text {hitung }}=$} \\
\cline { 1 - 4 } $\operatorname{Reg}(\mathrm{a} / \mathrm{b})$ & 1 & 3374,56 & 3374,56 & 27,57 \\
\hline Residu & 36 & 4161,66 & 122,40 & \\
\hline Total & $\mathbf{3 4}$ & $\mathbf{1 1 5 5 5 8}$ & $\mathbf{3 4 9 6 , 9 6}$ & \\
\hline
\end{tabular}

Berdasarkan tabel 4.6 hasil perhitungan keberartian koefisien regresi diperoleh $\square_{\square|c| c \mid}$ dengan $\square_{\square}$ pembilang $=1$ dan $\square_{\square}$ penyebut $=\mathrm{N}-2=36-2$ = 34 Pada taraf $\propto=0,05$ maka $F_{\text {tabel }}=F_{0,95(1,34)}=4,13$. Dengan demikian dapat dilihat bahwa $F_{\text {hitung }}>F_{\text {tabel }}$ yaitu $27,57>4,13$ maka $\mathrm{H}_{0}$ di tolak.

Tabel 4.7

Hasil Perhitungan Keberartian Koefisien Regresi Pada Kelas Kontrol 


\begin{tabular}{||c|c|c|c|c||}
\hline $\begin{array}{c}\text { Sumber } \\
\text { Varians }\end{array}$ & DK & JK & RJK & F \\
\cline { 1 - 4 } Reg (a) & 1 & 91708,03 & - & \multirow{2}{*}{$F_{\text {hitung }}$} \\
\cline { 1 - 4 } Reg(a/b) & 1 & 2728,38 & 2728,38 & 26,74 \\
\cline { 1 - 4 } Residu & 36 & 3468,59 & 102,02 & \\
\hline \hline Total & $\mathbf{3 4}$ & $\mathbf{9 7 9 0 5}$ & $\mathbf{2 8 3 0 , 4}$ & \\
\hline
\end{tabular}

Berdasarkan tabel 4.7 hasil perhitungan keberartian koefisien regresi diperoleh $\square_{\square(u \in \square}$ dengan $\square_{\square}$ pembilang $=1$ dan $\square_{\square}$ penyebut $=\mathrm{N}-2=36-2$ = 34 Pada taraf $\propto=0,05$ maka $F_{\text {tabel }}=F_{0,95(1,34)}=4,13$. Dengan demikian dapat dilihat bahwa $F_{\text {hitung }}>F_{\text {tabel }}$ yaitu $26,74>4,13$ maka $\mathrm{H}_{0}$ di tolak. maka dapat disimpulkan bahwa koefisien arah persamaan regresi cukup berarti.

\section{c. Uji Linieritas Regresi Pada Kelas Eksperiemen dan kelas Kontrol}

Untuk menguji linieritas regresi dirumuskan hipotesis sebagai berikut:

$$
\begin{aligned}
& \mathrm{H}_{0}=\text { Regresi linier } \\
& \mathrm{H}_{\mathrm{a}}=\text { Regresi non linier }
\end{aligned}
$$

Tabel 4.8

Analisis Varians Untuk Uji Kelinieran Model Regresi Kelas Eksperimen

\begin{tabular}{|l|c|c|c|c|}
\hline \hline $\begin{array}{l}\text { Sumber } \\
\text { Varians }\end{array}$ & DK & JK & RJK & F \\
\hline $\begin{array}{l}\text { Tuna } \\
\text { Cocok }\end{array}$ & 5 & $-94024,3$ & $-18804,86$ & $\begin{array}{c}\text { F }_{\text {hitung }}= \\
-5,5\end{array}$ \\
\cline { 1 - 4 } Kekeliruan & 29 & 98186 & 3385,72 & \\
\hline \hline \multicolumn{1}{|c|}{ Total } & 34 & $\mathbf{4 1 6 1 , 6 6}$ & $\mathbf{- 1 5 4 1 9 , 1 4}$ & \\
\hline \hline
\end{tabular}

Pada tabel 4.8 tersebut menunjukkan harga $F_{\text {tabel }}$ diperoleh $F$ dengan pembilang $=\mathrm{N}-\mathrm{K}=36-7=29$ dan $\square_{\square}$ penyebut $=\mathrm{K}-2=7-2=5$ pada taraf nyata $\square=0,05$ maka $F_{\text {tabel }}=F_{0,95(29,5)}=4,50$. Karena $\square_{\square 0 u(u \square}<$ yaitu $-5,5<4,50$ berarti $H_{0}$ diterima sehingga regresi $Y$ atas $X$ linier.

Tabel 4.9

Analisis Varians untuk Uji Kelinieran Model Regresi Pada Kelas Kontrol

\begin{tabular}{|l|c|c|c|c|}
\hline $\begin{array}{c}\text { Sumber } \\
\text { Varians }\end{array}$ & DK & JK & RJK & F \\
\hline $\begin{array}{l}\text { Tuna } \\
\text { Cocok }\end{array}$ & 5 & $-80777,7$ & $-16155,55$ & $F_{\text {hitung }}=-5,6$ \\
\hline
\end{tabular}




\begin{tabular}{|c|c|c|c|l|}
\hline Kekeliruan & 29 & 84246,3 & 2905,04 & \\
\hline \hline Total & 29 & $\mathbf{3 4 6 8 , 5 9}$ & $\mathbf{- 1 3 2 5 0 , 5 1}$ & \\
\hline
\end{tabular}

Pada tabel 4.9 tersebut menunjukkan harga $\mathrm{F}_{\text {tabel }}$ diperoleh $\mathrm{F}$ dengan pembilang $=\mathrm{N}-\mathrm{K}=36-7=29$ dan $\square$ penyebut $=\mathrm{K}-2=7-2=5$

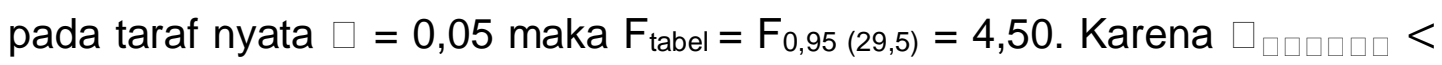
yaitu $-5,6<4,50$ berarti $H_{0}$ diterima sehingga regresi $Y$ atas $X$ linier Dari hasil perhitungan diperoleh harga thitung $=5,88$ Dengan taraf signifikan $5 \%(0,05)$ dan df 36 maka diperoleh ttabel 1,69 . Sehingga dapat dilihat thitung $>$ ttabel yaitu 5,88> 1,69 (Lampiran 36). Maka Ho ditolak.

Model pembelajaran kooperatif tipeThink Pair Share (TPS)terhadap kemampuan pemahaman konsep matematis siswa sebesar 50,41\%. Dengan demikian dapat dikatakan bahwa model pembelajaran kooperatif tipe Think Pair Share (TPS) terdapat pengaruh yang signifikan terhadap kemampuan pemahaman konsep matematis siswa.

Berdasarkan analisis pretest, hasil perhitungan diperoleh nilai rata-rata (ธ) untuk kelas eksperimen adalah 48,03dengan simpangan baku adalah 13,27.Sementara nilai rata-rata $(\bar{\square})$ kelas kontrol adalah 46,33dengan simpangan baku adalah 12,95. Sehingga dari analisis pretest kelas eksperimen diperoleh $L_{0}=0,1208$ sedangkan $L_{t}=0,1477$. Ini menunjukkan bahwa diperoleh $L_{0}<L_{t}$ pada uji normalitas, sementara itu analisis data awal pretest kelas kontrol diperoleh $L_{0}=0,1263$ sedangkan $L_{t}=0,1477$. Ini menunjukkan bahwa diperoleh $L_{0}<L_{t}$ pada uji normalitas. Uji homogenitas juga menunjukkan hasil yang sama seperti uji normalitas.

Proses pembelajaran selanjutnya kelas eksperimen mendapat perlakuan model pembelajaran kooperatif tipe Think Pair Share (TPS)dan untuk kelas kontrol dengan model pembelajaran konvensional yaitu pendekatan saintifik. Setelah proses pembelajaran berakhir, kelas eksperimen dan kelas kontrol diberi posttest.

Berdasarkan hasil tes yang telah dilakukan diperoleh nilai rata- rata kelas eksperimen adalah 54,78 dengan simpangan baku adalah 14,67. Sementara nilai rata-rata kelas kontrol 50,47dengan simpangan baku adalah 13,31. Sehingga dari analisis data akhir (posttest) kelas eksperimen diperoleh $L_{0}=0,1216$ sedangkan $L_{t}=0,1477$. Ini menunjukkan bahwa diperoleh $L_{0}<L_{t}$ pada uji normalitas, sementara itu analisis data akhir (posttest) kelas kontrol diperoleh $L_{0}=0,1463$ sedangkan $L_{t}=0,1477$. Ini menunjukkan bahwa diperoleh $L_{0}<L_{t} p a d a$ uji normalitas. Uji homogenitas 
juga menunjukkan hasil yang sama seperti uji normalitas. Jadi kesimpulannya adalah kedua kelas berasal dari kondisi yang sama.

Berdasarkan uji regresi linear sederhana diperoleh $r_{\text {tabel }}=0,329$, sementara berdasarkan perhitungan yang telah dilakukan diperoleh $\boldsymbol{r}_{\text {hitung }}=$ 0,71 . Dari perhitungan terlihat bahwa $r_{\text {hitung }}>r_{\text {tabel }}(0,71>0,329)$ maka hipotesis yang diajukkan diterima.

Tentu saja hal ini berkaitan dengan perlakuan yang diberikan pada kedua kelas. Pada kelas eksperimen langkah-langkah pembelajarannya adalah Think (berpikir), Pair (berpasangan), dan Share (berbagi), sehingga semua siswa lebih aktif bertanya dan bekerja sama dalam pasangannya menciptakan pola interaksi yang optimal. Sementara pada kelas kontrol langkah-langkah pembelajarannya adalah mengamati, menanya, mengeksplorasi, mengasosiasi dan mengomunikasi, sehingga banyak siswa yang malas untuk bertanya, dan pola interaksi hanya didominasi oleh siswa yang memiliki kemampuan tinggi .

Berdasarkan uraian di atas, dapat di simpulkan bahwa "Terdapat pengaruh yang signifikan model pembelajaran kooperatif Tipe Think Pair Share (TPS)terhadap kemampuan pemahaman konsep matematis siswa kelas X SMA Negeri 3 Binjai tahun pelajaran 2017/2018".

\section{Kesimpulan}

Berdasarkan analisis data yang telah disajikan dan pembahasan hasil penelitian yang telah diuraikan, dapat diambil kesimpulan sebagai berikut :Kemampuan pemahaman konsep matematis siswa dengan menggunakan model pembelajaran kooperatif tipe Think Pair Share (TPS) dapat dilihat dengan membandingkan rata-rata dua kelas. Pada kelas eksperimen ratarata kemampuan awal dari hasil pretest diperoleh 48,03 dan kelas kontrol diperoleh 46,33. Sedangkan rata-rata kemampuan pemahaman konsep matematis siswa pada kelas eksperimen dari hasil posttest, diperoleh 54,78 sedangkan pada kelas kontrol diperoleh 50,47.

Dengan demikian hipotesis yang diajukan diterima, sehingga dapat disimpulkan bahwa "Terdapat pengaruh yang signifikan penggunaan model pembelajaran kooperatif Tipe Think Pair Share (TPS) terhadap kemampuan pemahaman konsep matematis siswa kelas X SMA Negeri 3 Binjai tahun pelajaran 2017/2018".

\section{Daftar Pustaka}


Adesnayanti K. Duha, "Penerapan Model Think Pair Share terhadap Pemahaman Konsep Matematika", Jurnal Pendidikan Matematika, Volume 1, No. 1, 2012.

Aris Shoimin, 68 Model Pembelajaran Inovatif dalam Kurikulum 2013, Yogyakarta: Ar-Ruzz Media, 2014.

Herman Hudojo, Pengembangan Kurikulum dan Pembelajaran Matematika. Surabaya: Universitas Negeri Malang, 2005.

Iskandar Zulkarnain dan Soraya Djamilah, Penerapan Model Pembelajaran Think Pair Share Terhadap Kemampuan Pemahaman Matematis Siswa Sekolah Menengah Pertama, EDU-MAT Jurnal Pendidikan Matematika, Volume 3, Nomor 1, April 2015

Nana Sudjana, Metoda Statistika, Bandung: Tarsito, 2001.

Ngalim Purwanto, Prinsip-Prinsip dan Teknik Evaluasi Pengajaran (Bandung: Remaja Rosdakarya, 2010.

Relawati dan Nusrani, "Perbandingan Kemampuan Pemahaman Konsep Matematis Melalui Model Pembelajaran Core dan Pembelajaran Langsung pada Siswa SMP", Jurnal Kajian Pendidikan dan Pengajaran, Volume 2, No. 2, Oktober 2016.

Suharsimi Arikunto, Dasar-Dasar Evaluasi Pendidikan, Jakarta: Bumi Aksara, 2013.

Syaiful Sagala, Konsep dan Makna Pembelajaran, Bandung: Alfebeta, 2009.

Trianto, Mendesain Model Pembelajaran Inovatif-Progresif, Jakarta: Kencana Prenada Media Group, 2011.

Winda Verowita, "Pengaruh Penerapan Model Pembelajaran Kooperatif TipeThink Pair Share terhadap Pemahaman Konsep dalam Pembelajaran Matematika", Jurnal Pendidikan Matematika, Part 3 Volume 1, No. 1, 2012. 